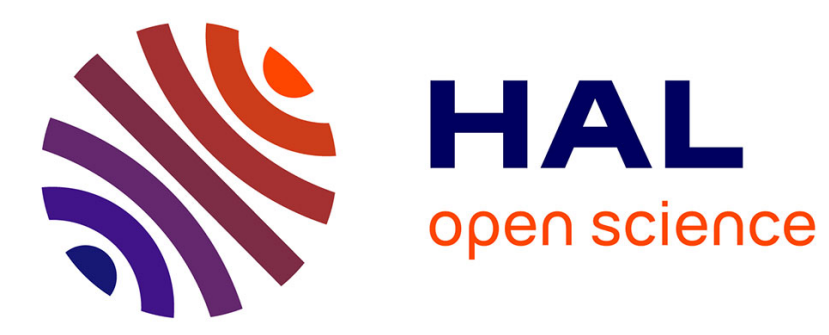

\title{
Stem cell therapy for neonatal brain injury: Perspectives and Challenges
}

Luigi Titomanlio, Annemieke Kavelaars, Jeremie Dalous, Shyamala Mani, Vincent El Ghouzzi, Cobi Heijnen, Olivier Baud, Pierre Gressens

\section{- To cite this version:}

Luigi Titomanlio, Annemieke Kavelaars, Jeremie Dalous, Shyamala Mani, Vincent El Ghouzzi, et al.. Stem cell therapy for neonatal brain injury: Perspectives and Challenges. Annals of Neurology, 2011, 70 (5), pp.698-712. 10.1002/ana.22518 . hal-02342669

\section{HAL Id: hal-02342669 \\ https://hal.science/hal-02342669}

Submitted on 2 Jun 2020

HAL is a multi-disciplinary open access archive for the deposit and dissemination of scientific research documents, whether they are published or not. The documents may come from teaching and research institutions in France or abroad, or from public or private research centers.
L'archive ouverte pluridisciplinaire HAL, est destinée au dépôt et à la diffusion de documents scientifiques de niveau recherche, publiés ou non, émanant des établissements d'enseignement et de recherche français ou étrangers, des laboratoires publics ou privés. 


\section{Stem Cell Therapy for Neonatal Brain Injury: Perspectives and Challenges}

Running title: Stem Cells and Perinatal Brain Damage

Luigi Titomanlio, ${ }^{1-4}$ Annemieke Kavelaars, ${ }^{5,}$ Jeremie Dalous, ${ }^{1-3,{ }^{*}}$ Shyamala Mani, ${ }^{6}$ Vincent El Ghouzzi, ${ }^{1-3}$ Cobi Heijnen, ${ }^{5}$ Olivier Baud, ${ }^{1-3}$ Pierre Gressens ${ }^{1-3,7}$

${ }^{1}$ Inserm, UMR-676, Hôpital Robert Debré, Paris, France

${ }^{2}$ Paris Diderot University, Sorbonne Paris Cité, UMR676, Paris, France

${ }^{3}$ PremUP, Paris, France

${ }^{4}$ AP-HP, Pediatric Emergency Department, Hôpital Robert Debré, Paris, France

${ }^{5}$ Laboratory of Neuroimmunology and Developmental Origins of Disease, University Medical Center, Utrecht, The Netherlands

${ }^{6}$ Center for Neuroscience, IISc, Bangalore, India

${ }^{7}$ Institute for Reproductive and Developmental Biology, Imperial College, Hammersmith Campus, London, United Kingdom

* These two authors contributed equally to this work.

Number of character/spaces in title: 72

Number of character/spaces in running head: 37

Abstract word count: 156

Manuscript word count (body only): 5439

Number of figures: 2

(Number of color figures: 2)

Number of tables: 1 
Stem cells and perinatal brain damage Titomanlio L. et al.

Keywords: brain injury, cerebral palsy, cell therapy

\section{Corresponding author:}

Pierre Gressens, MD, PhD

Inserm U676

Hôpital Robert Debré, 48 blvd Serurier

F-75019 Paris, France

Phone: +33140031 976; Fax: +33140031995

E-mail: pierre.gressens@inserm.fr

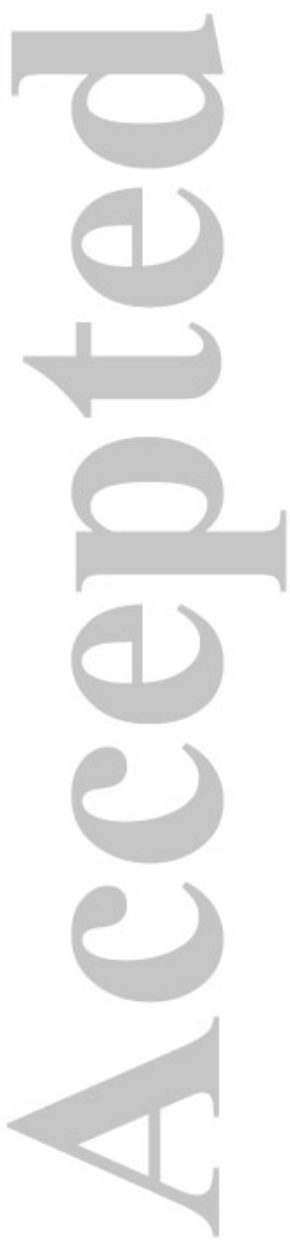


Stem cells and perinatal brain damage

Titomanlio L. et al.

\section{ABSTRACT}

Cerebral palsy is a major health problem caused by brain damage during pregnancy, delivery, or the immediate postnatal period. Perinatal stroke, intraventricular hemorrhage, and asphyxia are the most common causes of neonatal brain damage. Periventricular white matter damage (periventricular leukomalacia) is the predominant form in premature infants and the most common antecedent of cerebral palsy.

Stem cell treatment has proven effective in restoring injured organs and tissues in animal models. The potential of stem cells for self-renewal and differentiation translates into substantial neuroprotection and neuroregeneration in the animal brain, with minimal risks of rejection and side effects.

Stem cell treatments described to date used neural stem cells, embryonic stem cells, mesenchymal stem cells, umbilical cord stem cells, and induced pluripotent stem cells. Most of these treatments are still experimental.

In this review, we will focus on the efficacy of stem cell therapy in animal models of cerebral palsy, and we will discuss potential implications for current and future clinical trials.

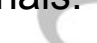


Stem cells and perinatal brain damage

Titomanlio L. et al.

\section{INTRODUCTION}

\section{Neonatal brain injuries and cerebral palsy (CP)}

Brain injury in premature infants is a major health problem worldwide. The incidence of preterm birth has increased, and improvements in survival rates have led to increased numbers of disabled patients despite a concomitant decrease in long-term neurodevelopmental disability rates. ${ }^{1-4}$

Perinatal stroke, intraventricular hemorrhage, and asphyxia are the most common causes of neonatal brain injury, with hypoxia-ischemia being the final common pathway of injury.

Periventricular white matter damage (PWMD, periventricular leukomalacia) is the predominant form of brain injury in premature infants and the most common antecedent of cerebral palsy (CP). Hypoxia/ischemia with or without systemic infection/inflammation is the main mechanism responsible for PWMD. Neuropathology studies show focal necrotic lesions within the white matter surrounding the lateral ventricles and/or the subsequent appearance of more widespread lesions ${ }^{5}$ related to apoptotic death of late oligodendrocyte progenitors. ${ }^{6,7}$ The main neuropathological feature of PWMD is marked hypomyelination. ${ }^{8}$ In addition to the white matter damage, the gray matter exhibits abnormalities including neuronal loss and impaired neuronal guidance. ${ }^{9}$ These findings support the view that some of the dysfunctions seen in preterm infants reflect decreased brain connectivity with impairments in the integration of information arriving from different areas of the brain. ${ }^{10,11}$

Children assessed several years after preterm birth often perform less well in tests of cognition, attention, executive function, and perception than do children born at full 
term. $^{12}$ The massive personal and economic burdens generated by long-term neurological morbidity, together with the high prevalence of perinatal brain damage, are of considerable concern, particularly as no effective treatment is available to date. ${ }^{13}$

\section{Animal models of cerebral palsy}

Because of the many developmental and functional differences between the neonatal brain and the adult brain, extrapolating adult data to neonates is generally unwise. Consequently, the efficacy of potential treatments should be tested in developmentally appropriate models. Several inflammation- or ischemia/hypoxia-based models of CP have been developed, mainly in rodents. ${ }^{14}$

Transient bilateral carotid artery stenosis leads to generalized brain ischemia, which selectively destroys specific cells. However, this model is associated with highly variable outcomes, ${ }^{15}$ and models of focal ischemia are therefore more commonly used. These models involve occlusion of the middle cerebral artery (MCA), which leads to infarction of the striatum and overlying cortex. Permanent occlusion is accomplished via laser-induced photothrombosis, ligation, or cauterization. ${ }^{16}$ Ischemia-reperfusion injury can be replicated by inducing transient occlusion ${ }^{17}$ using an intraluminal filament fed through the carotid artery into the proximal MCA. Animal models of hypoxia-ischemia have shown clearly that brain injury is followed by reduced myelination, ventricular enlargement, loss of neurons, damage to axons and dendrites, and alterations in neurobehavioral performance, ${ }^{18-21}$ thus reproducing common features of PWMD.

Experimentally induced inflammation has been used in a number of studies to model PWMD pathology and to test potential therapeutic interventions. The endotoxin lipopolysaccharide (LPS), a potent inducer of innate immune responses such as 
Stem cells and perinatal brain damage Titomanlio L. et al.

inflammation, ${ }^{22-24}$ administered intracerebrally during the early neonatal period or intraperitoneally to the pregnant dam, results in (neuro)-inflammation and hypomyelination in the offspring. ${ }^{25,26}$ Excitotoxicity is another key factor that contributes to the development of white and gray matter damage in the premature brain. ${ }^{9,27,28}$ Wellcharacterized animal models of excitotoxic damage involve activation of the excitotoxic cascade via the NMDA and metabotropic glutamate receptors. Ibotenate and quinolinate 29 induce white matter cysts, as well as cortical necrosis, reproducing the lesions observed in infants with PWMD.

\section{Cell therapy}

Cell therapy holds promise in various models of brain injury or disease ${ }^{30-33}$ Over the last two decades, numerous studies have evaluated the efficacy and/or feasibility of transplantation within the injured brain of stem cells or specialized progenitor cells of both neural and non-neural origin, in order to replace lost cells or to prevent damaged cells from dying. ${ }^{34,}{ }^{35}$ However, despite the wide availability of these cells and their common use in animal models of injury, few studies have focused on their protective/regenerative effect in models of perinatal brain damage. ${ }^{36-42}$

\section{Stem cell types}

Multipotency and self-renewal are the cardinal features of stem cells. Multipotency is the ability to differentiate into multiple cell types belonging to the same germ layer (endoderm, mesoderm, or ectoderm). Self-renewal is the ability to make identical copies via cell division. Stem cells have considerable proliferative potential. They can be derived from many human tissues (Figure 1). 


\section{Neural stem cells (NSCs)}

NSCs are found in the adult human brain, mainly in the subventricular zone (SVZ) and hippocampus. ${ }^{43,44}$ These cells give rise to the three cerebral cell types, namely, neurons, astrocytes, and oligodendrocytes. ${ }^{45}$ NSCs from exogenous sources can be isolated from many regions of the central nervous system and cultured in vitro as neurospheres. Neurospheres are heterogeneous cell collections that include true stem cells, committed progenitors, and differentiated progeny. NSCs can also be derived from embryonic or fetal brain tissue, and they generate oligodendrocytes, neurons, and astrocytes when allowed to differentiate spontaneously in serum-free media. ${ }^{46,47} \mathrm{NSCs}$ can differentiate into functional cellular subtypes ${ }^{48,49}$ such as cortical projection neurons, ${ }^{50}$ interneurons, ${ }^{51}$ and hippocampal pyramidal neurons. ${ }^{52}$

\section{Embryonic stem cells (ESCs)}

ESCs are derived from blastocysts during the 16-cell stage. They are pluripotent: they can give rise to all cell types within the developing embryo. ESCs can provide an almost unlimited supply of cells for transplantation. Unfortunately, ESCs form teratomas after in vivo transplantation. ${ }^{53,54}$ Purifying neural cells by removing tumorigenic pluripotent stem cells is feasible ${ }^{55}$ but the resulting cell population is probably not different from NSCs derived from other sources.

\section{Induced pluripotent stem cells (iPSCs)}

Induced pluripotent stem cells (iPSCs) can be obtained by inducing terminally differentiated somatic cells via nuclear reprogramming. Reprogramming has been 
Stem cells and perinatal brain damage Titomanlio L. et al.

achieved by transducing mouse ${ }^{56}$ or human ${ }^{57}$ fibroblasts with retroviral vectors containing cDNA encoding four genes (Oct3/4, Sox2, c-Myc, and Klf4). Recently, similar results were obtained by transducing fibroblasts with Oct4, Sox 2 , NANOG, and LIN28, ${ }^{58}$ a strategy having the major advantage of not using the proto-oncogene c-Myc. An advantage of iPSCs is the ability to generate cellular products for autologous grafts. Thus, the administration of iPSC-derived progenitors is not followed by a graft-versushost response. ${ }^{59} \mathrm{~A}$ recent study established that functional neurons, of which a small proportion also expressed markers of GABAergic neurons, could be obtained in mice from adult somatic cells without the intermediate iPSC step. ${ }^{60}$ Interestingly, the same procedure has been developed in humans, permitting for the first time the generation of hematopoietic progenitors and mature cells directly from human dermal fibroblasts, without establishing pluripotency. ${ }^{61}$ This strategy is ethically acceptable and, theoretically, eliminates the risk of tumor formation.

\section{Mesenchymal stem cells (MSCs)}

Bone marrow contains a non-hematopoietic stem cell, the mesenchymal stem cell (MSC). MSCs differentiate into mesodermal tissues, including bone, cartilage and fat. It has even been suggested that MSCs may differentiate into functional neurons. ${ }^{62,63}$ In vitro, MSCs have been shown to differentiate into neurons, astrocytes, and oligodendrocytes. ${ }^{64-67}$ In these studies, in vitro neural transdifferentiation by MSCs was assessed based on the detection of neural-related mRNAs and proteins in the treated cells. However several neural-related mRNAs and proteins are expressed by undifferentiated human MSCs. ${ }^{68}$ Moreover several studies have shown that in vitro neuronal differentiation protocols with chemical induction medium can produce 
unexpected and misleading effects, with cell morphology changes caused by rapid actin cytoskeleton disruption, cell shrinkage, and cellular toxicity. ${ }^{69-72}$ These studies indicate a need for a more cautious evaluation of MSC differentiation using dissection of molecular signaling and commitment events, in order to reliably assess the ability of MSCs to differentiate into neuronal lineages.

Apart from the bone marrow, non-embryonic tissues from which MSCs can be isolated include cord blood and the stroma of the umbilical cord and placenta. ${ }^{73} \mathrm{MSCs}$ can be expanded in vitro. This culture procedure usually takes at least 2-3 weeks, which is not consistent with early autologous MSC treatment after the insult. The immunogenicity of MSCs is extremely low, as MSCs lack expression of MHC Class-II antigens, which prevents the development of a graft-versus-host response. Moreover, MSCs have immunosuppressive activity and are even used to treat steroid-resistant graft-versus-host disease. ${ }^{74,75}$ This last feature may facilitate the transplantation of allogeneic MSCs, thus considerably improving treatment feasibility by allowing the administration of stored in vitro-expanded MSCs. Apart from their regenerative capacity, MSCs also exhibit anti-inflammatory properties, a feature that underlines their potential for the treatment of cerebral injury.

\section{Umbilical cord stem cells}

Umbilical cord blood contains many stem cell types such as $\mathrm{MSCs}^{76}$ and endothelial progenitor cells ${ }^{77}$, and has been demonstrated as a viable alternative to bone marrow transplantation. ${ }^{78,79}$ Pluripotent stem cells were recently isolated from cord blood. ${ }^{80}$ 
Stem cells and perinatal brain damage Titomanlio L. et al.

The whole mononuclear cell fraction, containing all cord blood stem cells, is easily obtained from cord blood and has been transplanted in different animal models with the goal of assessing its possible neuroprotective effects. ${ }^{81-84}$ Human umbilical cord blood mononuclear cells (HUCBCs) differentiate in vitro into virtually all mature cells ${ }^{85-89}$ and neural cells. ${ }^{80,90,91}$ In a few laboratories, iPSCs were recently generated from cord blood. $^{92}$

The many advantages of HUCBCs include ready availability with no harm to the baby or mother, a limited number of ethical issues, low immunogenicity, ${ }^{93}$ and beneficial effects in vivo in animal diseases. ${ }^{81,94,95}$

The connective tissue of the cord (Wharton's jelly) is also a promising source for regenerative treatments, as it can be used to generate relatively high numbers of MSCs, which exhibit greater proliferative activity compared to bone marrow. ${ }^{73,96}$

\section{Strategies for stem cell therapy Delivery routes and methods}

Stem cells may be delivered either systemically into the vasculature or locally into the brain (intraparenchymally, intraventricularly, and intrathecally) ${ }^{52,} 97$ (Figure 2). Many stem cells are capable of migration toward a focus of injury. ${ }^{39} \mathrm{NSC}$ are more frequently delivered directly into the brain, whereas MSCs are usually given systemically. Recently, we showed that intranasal delivery of stem cells was a useful and non-invasive method. ${ }^{41}$ The stem cells cross the cribiform plate and migrate through the brain via the rostral migratory route..$^{98}$

\section{Cell dose}


Stem cells and perinatal brain damage

Titomanlio L. et al.

The appropriate dose of cells for transplantation depends on several factors, of which the most crucial is the host environment. ${ }^{99}$ The goal is to obtain the greatest local benefits using the smallest possible number of viable transplanted cells in order to reduce the risk of toxicity.

In a hostile microenvironment, for instance in an area of acute brain injury, a large number of cells may be needed to achieve effective neuroprotection, neuroregeneration, and local repair modulation. However, implantation of large numbers of cells into a small intraparenchymal site may affect cell viability and differentiation. Moreover, when gliotic changes begin, the volume of cells that can be accepted physically at an injury site is limited, even when slow administration rates are used. ${ }^{100}$ Strategies that are being evaluated in several animal models include multisite intracerebral injections; prolonged intraventricular, intrathecal, or intravenous infusion; and repeated cell grafting over time. ${ }^{52,97,101,102}$ Our recent studies indicate that intracranial administration of 100,000 MSCs into the neonatal mouse brain 10 days after the insult is sufficient to improve outcomes. ${ }^{40,103}$

\section{Timing of transplantation}

Most neuroprotective agents have a relatively narrow therapeutic time window to be effective. The window for cell therapy remains ill-defined, and the effect of stem cells varies across disease models. This variability reflects the ability of stem cells to act as neuroprotective agents, as a source of cells for in vivo replacement (neuroregeneration), or as both. ${ }^{104}$ Whereas neuroprotection may be suitable for the treatment of acute brain injury, the treatment of chronic neurodegenerative diseases requires both neuroprotective and cell replacement strategies. When using animal models of CP, 
Stem cells and perinatal brain damage

Titomanlio L. et al.

many groups transplant the cells 4 to 48 hours following acute injury. However, benefits have been observed with cell delivery up to 10 days after cerebral hypoxia-ischemia. ${ }^{41}$ Such findings may suggest mechanisms of action other than neuroprotection or in addition to neuroregeneration, such as enhancement of endogenous cerebral plasticity.

In acute human brain disorders such as stroke, the efficacy of therapeutic interventions is directly related to the time to implementation. ${ }^{105,106}$ In animal models of stroke, administration of MSCs 3-24 hours after MCA occlusion diminished cell apoptosis by $50 \%$ in the ischemic penumbra. ${ }^{107-109}$ From a clinical point of view, whether stem cells are appropriate in newborns shortly after an acute brain insult is debatable. In this specific clinical situation, activated microglia/macrophages play a central pathophysiological role, ${ }^{110,111}$ and inflammatory cytokine production by these cells may partly inhibit stem cell-mediated repair processes. In addition, stem cell transplantation may result in a systemic inflammatory response that may enhance microglial activation at the lesion site and worsen the white matter damage through immature oligodendrocyte death and oligodendroglial cell maturation arrest. ${ }^{7}$ Also, stem cell infusion has been associated with pulmonary thrombosis in children ${ }^{112,113}$ and with a decrease in cerebral blood flow in rats. ${ }^{114}$ In acute hypoxic-ischemic injury, cerebral vessel occlusion after cell transplantation may dramatically worsen the effects of the perinatal brain insult.

Therapeutic effects of MSCs transplanted immediately after the insult may be chiefly ascribable to inhibition of neuroinflammation and apoptosis. When the cells are administered a few days or even a few weeks after the insult, functional improvements may be related to endogenous repair processes such as neurogenesis, angiogenesis, and synaptogenesis. For the development of future therapeutic interventions, working on 
Stem cells and perinatal brain damage

Titomanlio L. et al.

the therapeutic window is probably crucial. More specifically, we need to investigate the mechanisms of action of MSCs at a given time point after the insult. To obtain proof of concept in mice subjected to excitotoxic injury, we compared NSC therapy given 4 or 72 hours postinjury. The behavioral evaluation showed severe memory function impairments without treatment contrasting with normal memory in mice given NSCs 4 hours postinjury. This effect was mainly due to a neuroprotective mechanism. ${ }^{39}$ Mice treated 72 hours after lesion showed partial memory function recovery. These data suggest that an intervention can be effective even when given late, after the inflammatory and apoptotic storm has subsided. As discussed above, inflammation leads to local microglial activation, inhibiting endogenous neurogenesis and suppressing the growth and survival of transplanted cells. ${ }^{115}$ On the other hand, inflammation also activates local repair, facilitating transplanted cell homing, growth, integration, and survival after acute injury. ${ }^{116-118}$

Better defining therapeutic windows in $\mathrm{CP}$ models, as well as the pathophysiological mechanisms involved, may help to achieve optimal integration of the newly formed cells into functional networks, thereby providing histological and behavioral improvements.

\section{Monitoring}

Clinical studies require noninvasive methods for monitoring the migration dynamics and viability of transplanted cells. Currently, there is no validated method for tracking transplanted stem cells in human patients, as bioluminescence and fluorescence techniques are not suitable for use in humans. In myelin diseases, myelin formation analysis may allow monitoring of in vivo NSC migration and engraftment. ${ }^{119-121}$ 
Alternatively, labeling of human NSCs (HuNSCs) grown with magnetic nanoparticles allows NSC detection by cerebral magnetic resonance imaging (MRI) in rodents ${ }^{122,123}$ and would probably be useful also in humans. Metabolic markers have been tested and quantified in the human brain using proton nuclear MR spectroscopy. ${ }^{124}$ Unfortunately, the amount of NSC metabolic biomarker decreases dramatically with increasing stem cell age, leading to potential misinterpretation of data. Other techniques are being evaluated such as the use of viral vectors to deliver genes to stem cells encoding proteins detectable on MRI scans. ${ }^{125}$ However, before these techniques enter clinical trials, the use of genetically modified HuNSCs for in vivo tracking will have to be approved.

In animal studies stem cells can easily be labeled using a fluorochrome and traced throughout the period of regeneration.

\section{$r$}

\section{Engraftment or stimulation of endogenous regeneration?}

Originally, the positive effects of stem cell transplantation were attributed to donor cell engraftment in the lesion site. MSCs express neuronal proteins and differentiate in vitro to respond to depolarizing stimuli. ${ }^{64,65,126}$ Data indicate that MSCs can differentiate into functional neurons. ${ }^{62,63}$ However, in a recent qPCR study of mice on postnatal day 9 (P9), we showed that after successful intracranial eGFP+-MSC transplantation 3 and 10 days after hypoxia-ischemia, less than $1 \%$ of the MSCs were traced 18 days after the last stem cell dose. Thus, at least in models of neonatal hypoxia-ischemia, MSCs may function merely as regulators of endogenous regeneration rather than as a substitute for damaged tissue (Van Velthoven et al., manuscript submitted). In this respect, it is worth noting that MSCs produce myriad growth and differentiation factors such as BDNF, 
Stem cells and perinatal brain damage

Titomanlio L. et al.

BMP, CSF, NGF, EGF, interleukins, neurotrophin, Persepin, Spp1, TGFb, VEGF, and others. These factors may change the local milieu, thereby acting as inducing signals enabling endogenous regeneration (Van Velthoven et al. manuscript submitted and ${ }^{40,}$ $\left.{ }^{41}\right)$.

\section{Toxicity}

\section{Immune response}

The central nervous system has been viewed as an immunologically isolated site protected by an impermeable blood-brain barrier (BBB). However, recent studies suggest that activated lymphocytes may cross the BBB at sites of injury and that resident microglia may have antigen-presenting capacity. ${ }^{127}$ Although NSCs are minimally immunogenic, chronic low-grade rejection of transplanted NSCs remains possible. Furthermore, bone marrow-derived transplants can cause an inflammatory response and acute rejection, ${ }^{128}$ especially when they contain CD34+ hematopoietic stem cells. Systemic administration of stem cells can also modify the immune response by modifying cytokine production. ${ }^{129}$ Clinical investigators therefore believe that some form of immunosuppression is necessary to optimize donor cell engraftment and survival in humans, by blocking T-cell activation. This strategy has been studied in only a few patients with Parkinson disease ${ }^{130,131}$ or Huntington disease ${ }^{132,133}$ treated with fetal cell transplantation. Given the potentially serious side effects of immunosuppression, this topic will gain in importance in future clinical trials of stem cell treatments. The development of noninvasive means of monitoring cell engraftment will help to assess the need for immunosuppression. ${ }^{134}$ 
Stem cells and perinatal brain damage

Titomanlio L. et al.

\section{Tumors}

ESCs and iPSCs have substantial significant teratogenic potential after implantation into host tissues, due to their pluripotency. ${ }^{53,54}$ Non-ESC-derived NSCs and MSCs are usually considered non-tumorigenic. ${ }^{135-138}$ Unfortunately, a recent report from Russia described a young patient with teleangiectasia ectatica who developed several histologically proven neuroblastomas probably derived from HuNSC transplants. ${ }^{139}$ Because the immunodeficiency associated with telangiectasia ectatica might have accounted for this complication, several methods were used to demonstrate that the tumor was not due to chromosomal and genetic instability in the patient. The results supported a nonhost origin to the tumors. The NSCs used in this patient for repeated intracerebral transplantation were derived from periventricular tissue isolated from several fetuses aborted at 8-12 weeks of gestation. Conceivably, the relatively poor purity of these cells may have contributed, at least in part, to tumor formation in this patient. This report confirms the need for a detailed safety assessment of stem cell treatments via well-conducted clinical trials.

\section{Stem cell therapy in animal models of cerebral palsy}

Stem cell treatments have been tested in various animal models of CP. Almost all types of stem cells produced beneficial effects in rodents (see Table). Brain injury in these models is not limited to a single cell type but instead affects heterogeneous cell populations. This heterogeneity is desirable, as it replicates observations in humans after neonatal brain injury. Research on stem cell therapy in this field has therefore focused on a mix of progenitor cells, whereas a single cell type has often been used in 
other developmental disorders (e.g., oligodendrocyte progenitor cells in mouse models of congenital demyelination $\left.{ }^{140}\right)$.

Stem cell therapy has been studied chiefly in focal lesions. Focal lesions are highly reproducible ${ }^{41,141}$ and allow a histological comparison with the non-injured hemisphere. Another advantage of studying focal lesions is that injury to different cerebral areas causes different phenotypes. ${ }^{142-144}$ The efficacy of stem cell therapy in these models provides useful information about the pathophysiology of brain damage in full-term and preterm infants.

\section{Embryonic stem cells (ESCs)}

ESCs have been tested in postnatal day-12 mice with ligation of the right carotid artery. ${ }^{38}$ NSCs derived from ESCs by retinoic acid-induced differentiation were injected into the striatum 2 or 7 days after ligation, and hemispheric brain atrophy was measured 4 weeks after ligation. Hemispheric brain atrophy was less severe in the pups treated 2 days postligation, but not in those treated 7 days postligation, compared to vehicleinjected ligated controls. In 3 of the 10 surviving stem cell-injected animals, the transplanted cells formed tumors that contained very abnormal structures. ${ }^{38}$ Teratoma formation appears to correlate with the degree of cell differentiation and enrichment in culture. ${ }^{145}$ It is possible that ESCs were transplanted with the ESC-derived NSCs, accounting for the tumor formation. Indeed, in transplants of cells derived from ESCs, the main challenge is elimination of tumorigenic cells from the progenitor populations. ${ }^{145}$

\section{Neural stem cells (NSCs)}


Stem cells and perinatal brain damage

Titomanlio L. et al.

The therapeutic potential of NSCs in acute neonatal brain injuries has been evaluated in rodent excitotoxic and ligature models. The mouse pup model of ibotenateinduced brain injury is a classic excitotoxic injury model for white and gray matter damage in human cerebral palsy. ${ }^{141}$ We recently reported that early (4-hour) and late (72-hour) neurosphere-derived precursor cell (NDP) implantation significantly reduced brain lesion size in this neonatal model. ${ }^{39}$ The implanted cells, modified in vitro prior to transplantation toward the oligodendrocytic lineage, were capable of migrating toward the lesion site even when implanted contralaterally to the lesion, a feature similar to the long-distance migration of NSCs seen in a hypoxic-ischemic model of brain injury. ${ }^{118}$ At the lesion site, the NDPs underwent transient differentiation into neurons and oligodendrocytes but not astrocytes, suggesting that fate specification was achieved by the culture conditions. In parallel with the reduction in lesion size, the injured mice displayed a persistent and marked improvement in temporal and spatial memory at 3 and 6 weeks of age compared to littermates given intracerebroventricular injections of PBS or fibroblasts. The cells finally died in situ. Thus, even NDPs that do not survive can modify the functional impact of brain injury in neonates.

HuNSCs derived from ESCs were tested in mouse pups with excitotoxic lesions induced by the NMDA receptor agonist quinolinic acid. ${ }^{146}$ Three days after the injury, the mice received intraparenchymal injections of HuNSCs, which were labeled in vitro for in vivo tracking. The cells migrated to the sites of injury, and subsets expressed neuronal and glial cell markers, partially restoring the striatal neurons in the brain-damaged mice.

More recently, HuNSCs derived from ESCs and genetically engineered for in vivo molecular imaging and histological tracking were tested in a rat model of permanent left carotid artery ligation followed by hypoxia. ${ }^{147}$ HuNSCs were transplanted in the ischemic 
left hemisphere in the newborn pups 24 hours after the brain injury. Transplanted animals had significantly better behavioral performances compared to the shamoperated controls. Bioluminescence imaging permitted real-time tracking of the grafted cells, which showed good survival, dispersion, and differentiation.

\section{Mesenchymal stem cells (MSCs)}

Transplantation of MSCs derived from bone marrow has been shown to promote functional neurologic recovery in various models of neonatal and adult cerebral damage and confers neurogenesis, oligodendrogenesis and axonal remodeling and rewiring. ${ }^{148-}$ 150

The overall efficacy of stem cell treatment is greater in neonatal than in adult models of cerebral ischemia. This difference may be ascribable to the fact that the potential for endogenous neurogenesis continues throughout life but declines with age, so that neonates have a greater potential for regenerating lost neurons compared to adults. ${ }^{151-153}$ We recently showed that two administrations of bone marrow-derived MSCs to neonatal mice 3 and 10 days after unilateral right carotid artery occlusion on P9 produced a $46 \%$ improvement in sensorimotor function as observed in the cylinder rearing test and a $60 \%$ decrease in neuronal loss, compared to vehicle-treated animals. Moreover, we observed cellular proliferation and differentiation of the proliferated cells into cells expressing neuronal, oligodendroglial and astrocyte markers. Interestingly, the number of proliferating microglia decreased after MSC transplantation, possibly as a result of the well-known anti-inflammatory effects of MSCs. ${ }^{40,} 103$ Finally, two MSC administrations induced extensive remodeling of the corticospinal tract with increased axon density and activity when analyzed by anterograde tracing with bovine dextran 
Stem cells and perinatal brain damage Titomanlio L. et al.

amine or retrograde tracing with pseudo rabies virus ( ${ }^{103}$ and Van Velthoven et al., unpublished results). Interestingly, remodeling of the corticospinal tract correlated with sensorimotor improvement. These data demonstrate that MSC transplantation into human neonates with cerebral damage may constitute a promising and realistic treatment modality for regenerating the damaged neonatal brain.

\section{Human umbilical cord blood mononuclear cells (HUCBCs)}

When HUCBCs were injected into non-injured neonatal rodent brains, they showed relatively good engraftment with $20 \%$ of cells surviving for one month. ${ }^{154}$ About $2 \%$ of the cells differentiated into astrocytes and neurons, indicating good adaptation to the host environment. In a rat model of spastic paresis induced by hypoxia-ischemia, ${ }^{82}$ HUCBCs injected intraperitoneally 24 hours after the insult were found exclusively in the damaged hemisphere and exhibited no evidence of differentiation. This cell homing was associated with an improvement in motor function. ${ }^{82}$ The chemokine SDF-1, which is secreted by astrocytes, has been suggested as an important player for attracting HUCBCs expressing the SDF-1 receptor (CXCR4). ${ }^{116}$ In the same model of neonatal hypoxic-ischemic brain damage (Rice-Vannucci model), intraperitoneal injection of HUCBCs 3 hours posthypoxia reduced microglial activation in the cortex and caspase- 3 mediated cell death in the striatum. ${ }^{81}$ HUCBC transplantation resulted in improved functional outcomes as measured using negative geotaxis and cliff aversion reflexes. However, contrary to the previously cited work, ${ }^{82}$ very few cells reached the injured sites in the cerebral cortex and striatum. Furthermore, other authors showed no cognitive improvement or attenuation of structural damage after the intravenous administration of high HUCBC doses. ${ }^{84}$ More recently, low doses of intravenously injected HUCBCs 
Stem cells and perinatal brain damage

Titomanlio L. et al.

induced behavioral improvements in the Rice-Vannucci rat model. This effect was potentiated by the use of the BBB permeabilizer mannitol and was associated with upregulation of brain neurotrophic factors. ${ }^{83}$ In this work, only a few cells were found in the injured hippocampal dentate gyrus.

Altogether, these results indicate that experimental parameters relevant to HUCBC therapy, such as cell dose, timing of the injection(s), and delivery route, still need to be extensively investigated.

\section{Mechanisms of action: mostly hypotheses}

Although stem cells can differentiate into neurons, oligodendrocytes, astrocytes and, possibly, endothelium, ${ }^{35,155}$ neuroregeneration by cell replacement after brain injury might not represent their main mechanism of action. As reported above, stem cells can survive after transplantation, tend to migrate toward injured areas, ${ }^{156}$ and can generate functional neurons ${ }^{50}$ that may form connections with host cells. ${ }^{157}$ Neuroprotective ${ }^{39,} 158$ and immunomodulatory ${ }^{97,} 159$ effects are possible mechanisms in addition to cell replacement. ${ }^{160}$ The effects of stem cells may include, without being limited to, attenuation of central nervous system inflammation, secretion of survival-promoting neurotrophic factors, stimulation of the plastic response or neural activity in damaged host tissue, and restoration of synaptic transmitter release via the provision and/or promotion of local re-innervation. ${ }^{161-165}$ Promotion of central nervous system repair by these bystander effects is due to the extraordinary capacity of in vivo stem cells to find the best route to certain favorable niches, where they survive and act via interaction with various cell types in the micro-environment. ${ }^{166,167}$ This interaction is mainly related to integrins, which are proteins that act via inside-out and outside-in signaling to control 
Stem cells and perinatal brain damage Titomanlio L. et al.

many cell functions such as survival, differentiation, migration, and adhesion. The varied integrin expression displayed by stem cells of different tissue origins and the importance of integrin-mediated signaling and adhesion during development highlight the need for elucidating the signaling mechanisms involved. ${ }^{168}$ Specific surfaces for stem cell derivation, maintenance, proliferation, and differentiation were developed recently. These surfaces mimic the complex cellular environment existing in vivo, allowing tailoring of tissue culture environments to individual stem cell lines, and are suitable for clinical applications. ${ }^{168,169}$

Although stem cells can survive after transplantation, long-term survival of engrafted cells does not seem needed to improve outcomes. Recent work by our group indicates that intracranially applied MSCs decline gradually, although their regenerative effects persist over time. Grafted stem cells induce activation of endogenous stem cell compartments and a global decrease in microglial activity. ${ }^{170}$ Although all these mechanisms have been described, the mechanisms underlying the benefits of stem cell therapy may vary across animal models. It is worth noting that most studies did not show substantial changes in both morphology and behavior after stem cell transplantation. ${ }^{84,156,171}$ However, in our studies using bone marrow-derived MSCs in a mouse model of hypoxia-ischemia, MSC transplantation led to recovery of sensorimotor function; proliferation and differentiation into neurons, astrocytes, and oligodendrocytes; and rewiring of the corticospinal tract. ${ }^{40,41,103}$

\section{Stem cell therapy in neonates with brain injury}

\section{Clinical trials with NSCs}


Human NSCs are becoming very attractive cells for transplantation, because of their stable expansion and in vitro differentiation into neurons and oligodendrocytes. Fetal tissue-derived NSCs have been used in preclinical mouse studies. When transplanted intracerebrally in mice with a disorder resembling infantile neuronal ceroid lipofuscinosis (NCL, Batten's disease), these NSCs showed robust engraftment, extensive migration, and production of sufficient enzyme levels to alter host neuropathology. ${ }^{172}$ The first FDA-approved open-label, dose-escalating phase I clinical trial with HuNSCs was completed in January 2009 (http://clinicaltrials.gov/ct2/show/NCT00337636). HuNSCs were transplanted into 6 patients in the advanced stages of Batten's disease, directly into the brain parenchyma. Two dose levels were tested (500 million and 1 billion cells), and patients received immunosuppressive therapy for 12 months. The safety profile was favorable and longterm survival of the transplanted cells was documented. A second phase I clinical trial in patients with Pelizaeus-Merzbacher disease (PMD), another central nervous system disorder characterized by defective myelination, has received FDA approval and is under way at the University of California in San Francisco. This clinical trial is expected to enroll 4 patients with connatal PMD, who will receive stem cell transplants and immunosuppression for 9 months. The expected primary completion date is December 2012 (http://clinicaltrials.gov/ct2/show/NCT01005004).

\section{Clinical trials with HUCBCs}

HUCBCs were used in a clinical trial to treat young infants with Krabbe's syndrome. ${ }^{173}$ Krabbe's syndrome is a leukodystrophy due to a disorder in the metabolism of galactocerebroside, one of the main lipid components of myelin. This 
Stem cells and perinatal brain damage

Titomanlio L. et al.

disease usually begins during the first few postnatal months, causing severe loss of motor skills and often death before 2 years of age. In this trial, significant improvements with progressive central myelination and gains in neurodevelopmental functions were shown only in those infants given mononuclear HUCBCs before symptom onset. Very recently, a pilot study of autologous cord blood infusion was performed in 184 infants with acquired neurological disorders. ${ }^{174}$ This retrospective study supported the safety of intravenous autologous HUCBC infusion. Finally, two randomized, blinded, placebocontrolled clinical trials designed to evaluate possible beneficial effects of autologous umbilical cord blood infusion in infants with established CP are ongoing at the Medical College of Georgia (USA, http://clinicaltrials.gov/ct2/show/NCT01072370) and at the Duke University (USA, http://clinicaltrials.gov/ct2/show/NCT01147653), respectively.

Based on animal models of hypoxic-ischemic encephalopathy, HUCBCs and MSCs may be the most promising stem cells, as they are effective and potentially available for human studies. HUCBCs have advantages over MSCs that may support their use for neonatal insults. First, HUCBCs can be harvested very easily with no harm to the baby or mother. They have better proliferative capacities compared to MSCs. As they are less mature than stem cells from adult tissues, they are probably less immunogenic. This feature is associated with a lower risk of graft-versus-host disease in recipients of transplants from unrelated donors, even when there is some degree of HLA mismatch. ${ }^{79,93,175}$ Moreover, HUCBCs have a low rate of viral infection, ${ }^{175}$ and their use for newborns or children is particularly appropriate as one cord usually contains a sufficient number of cells for use in a low-body-weight patient. Finally, the use of cord blood improves the availability of stem cells for ethnic groups that are under-represented in bone marrow donor registries. 


\section{Perspectives}

The most extraordinary promises held by stem cells are flexibility, adaptive growth, and improved host acceptance. Immunosuppression is a critically important aspect of moving stem cell treatments to clinical applications in humans. In the future, the need for immunosuppression may be obviated by the use of generated cells that are genetically identical to the patient. ${ }^{176,177}$ Human mature neurons may soon be obtained from adult somatic cells without the intermediate iPSC step. ${ }^{60,61}$ Furthermore, given their ability to migrate toward areas of injury, stem cells may prove to be appropriate vehicles for delivering specific molecules that may not achieve sufficient concentrations in the injured area when given systemically. ${ }^{178}$ Candidate drugs for such ex vivo stem cellassisted gene therapy may include antiinflammatory, proangiogenic, and prosurvival molecules. $^{179}$

Current areas of concern include the risk for tumor formation, the lack of evidence that iPSC-derived neurons are functional, and the paucity of data indicating that stem cell transplantation provides clinically meaningful benefits in humans. Importantly, preclinical data showing neural protection should not be misinterpreted as evidence that these stem cell approaches are effective in patients with established CP. For the moment, clinical data are not available. Further studies are needed to fully understand the mechanisms involved in stem cell-mediated neuroprotection/neuroregeneration in animal models before cell therapy can be considered for newborns with CP. 
Stem cells and perinatal brain damage Titomanlio L. et al.

\section{ACKNOWLEDGMENTS}

This work was supported by the INSERM, Paris Diderot University, PremUP, Seventh Framework Program of the European Union (grant agreement no. HEALTH-F2-2009241778/Neurobid), Cefipra, Fondation Leducq, Associazione Italiana Niemann-Pick, Fondation Grace de Monaco, Fondation de l'avenir pour la recherche médicale appliquée, and AP-HP (Interface Contract to Dr Pierre Gressens). We are grateful to Jean-Pierre Laigneau for his help in drawing manuscript figures.
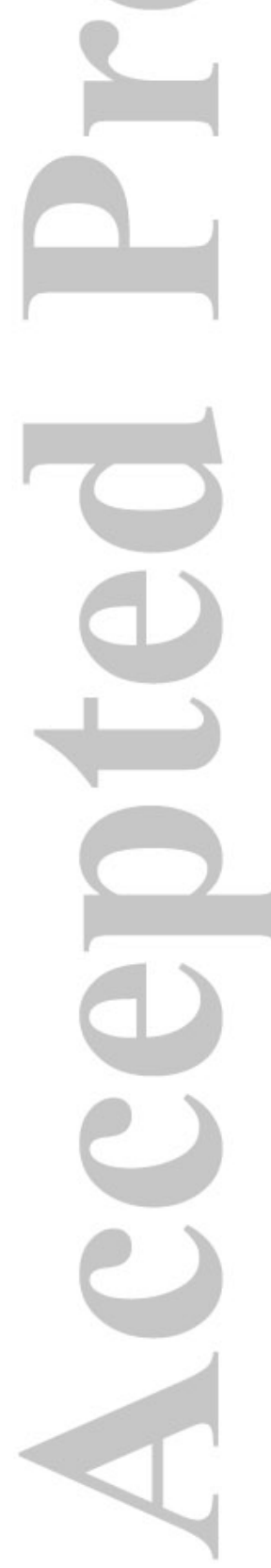
Stem cells and perinatal brain damage

Titomanlio L. et al.

\section{FIGURE LEGENDS}

Figure 1: Neural stem cell sources, cultured in vitro as neurospheres and giving rise to differentiated neurons, astrocytes, and oligodendrocytes.

Figure 2: Systemic and intracerebral routes of stem cell delivery to the brain.
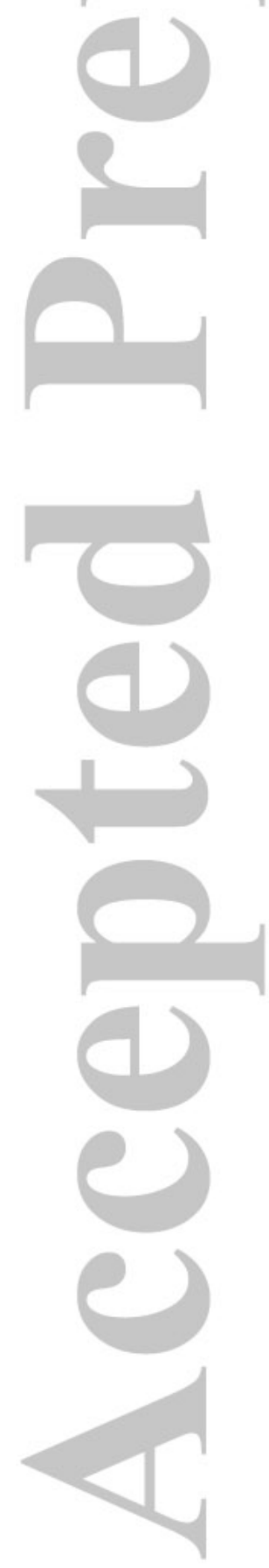
Stem cells and perinatal brain damage Titomanlio L. et al.

Table: Stem cell types used in neonatal brain injury models.

\begin{tabular}{|c|c|c|c|c|c|}
\hline Cell type & $\begin{array}{l}\text { Route; time after } \\
\text { injury }\end{array}$ & $\begin{array}{l}\text { Animal } \\
\text { model }\end{array}$ & $\begin{array}{l}\text { Functional } \\
\text { outcome }\end{array}$ & Cellular effect & Reference \\
\hline $\begin{array}{l}\text { Fetal cortex } \\
\text { (ED 13) }\end{array}$ & $\begin{array}{ll}\text { Intracerebral; } & 7 \\
\text { days } & \end{array}$ & P7 rats & $\mathrm{NE}$ & Graft survival & 180 \\
\hline $\begin{array}{l}\text { Fetal cortex } \\
\text { (ED 16) }\end{array}$ & $\begin{array}{l}\text { intracerebral; } 3 \\
\text { days }\end{array}$ & P7 rats & $\begin{array}{l}\text { Improved } \\
\text { performance }\end{array}$ & $\mathrm{NE}$ & 181 \\
\hline ESCs & $\begin{array}{l}\text { Intracerebral; } 2 \\
\text { days }\end{array}$ & P12 mice & $\mathrm{NE}$ & $\begin{array}{l}\text { Decreased neural } \\
\text { death }\end{array}$ & 38 \\
\hline ESCS & $\begin{array}{ll}\text { intracerebral; } & 2 \\
\text { days }\end{array}$ & P7 mice & $\begin{array}{l}\text { Improved } \\
\text { performance }\end{array}$ & $\begin{array}{l}\text { Increased number } \\
\text { of neurons }\end{array}$ & 182 \\
\hline NSCs & $\begin{array}{l}\text { intraventricular; } \\
24 \text { hours }\end{array}$ & P7 rats & $\mathrm{NE}$ & $\begin{array}{l}\text { Reduced brain } \\
\text { damage }\end{array}$ & 183 \\
\hline NSCs & $\begin{array}{ll}\text { intracerebral; } & 4 \\
\text { and } 72 \text { hours } & \end{array}$ & P5 mice & $\begin{array}{l}\text { Improved } \\
\text { performance }\end{array}$ & $\begin{array}{ll}\text { Reduced lesion } \\
\text { size }\end{array}$ & 39 \\
\hline HuNSCs & $\begin{array}{l}\text { intracerebral; } \\
\text { days }\end{array}$ & P5 mice & $\mathrm{NE}$ & $\begin{array}{l}\text { Decreased neural } \\
\text { death }\end{array}$ & 146 \\
\hline HuNSCs & $\begin{array}{l}\text { intracerebral; } 24 \\
\text { hours }\end{array}$ & P7 rats & $\begin{array}{l}\text { Improved } \\
\text { performance }\end{array}$ & $\begin{array}{l}\text { Increased } \\
\text { neurogenesis } \\
\end{array}$ & 147 \\
\hline MSCs & $\begin{array}{lr}\text { intracerebral } & \text { or } \\
\text { intravenous; } & 7 \\
\text { days } & \\
\end{array}$ & P7 rats & $\begin{array}{l}\text { Improved } \\
\text { performance }\end{array}$ & Reduced cell loss & 148 \\
\hline MSCs & $\begin{array}{ll}\text { intravenous; } & 3 \\
\text { days }\end{array}$ & P7 rats & $\begin{array}{l}\text { Improved } \\
\text { performance }\end{array}$ & No effects & 184 \\
\hline MSCs & $\begin{array}{l}\text { intracerebral; } \\
\text { days }\end{array}$ & P9 mice & $\begin{array}{l}\text { Improved } \\
\text { performance }\end{array}$ & $\begin{array}{l}\text { Increased } \\
\text { neurogenesis }\end{array}$ & 40 \\
\hline MSCs & $\begin{array}{l}\text { Intranasal; } 10 \\
\text { days }\end{array}$ & P9 mice & $\begin{array}{l}\text { Improved } \\
\text { performance }\end{array}$ & $\begin{array}{l}\text { Reduced lesion } \\
\text { size }\end{array}$ & 41 \\
\hline MSCs & $\begin{array}{l}\text { intracerebral; } \\
\text { and } 10 \text { days }\end{array}$ & P9 mice & $\begin{array}{l}\text { Improved } \\
\text { performance }\end{array}$ & $\begin{array}{ll}\begin{array}{l}\text { Reduced lesion } \\
\text { size }\end{array} & \\
\end{array}$ & 103 \\
\hline HUCBCs & $\begin{array}{l}\text { intraperitoneal; } 24 \\
\text { hours }\end{array}$ & P7 rats & $\begin{array}{l}\text { Improved } \\
\text { performance }\end{array}$ & $\begin{array}{l}\text { No reduction in } \\
\text { lesion size }\end{array}$ & 82 \\
\hline HUCBCs & $\begin{array}{l}\text { intraperitoneal; } 3 \\
\text { hours }\end{array}$ & P7 rats & $\begin{array}{l}\text { Improved } \\
\text { performance }\end{array}$ & $\begin{array}{l}\text { Decreased neural } \\
\text { death }\end{array}$ & 81 \\
\hline HUCBCs & $\begin{array}{l}\text { intravenous; } \\
\text { hours }\end{array}$ & $\mathrm{P} 7$ rats & No effect & No effect & 84 \\
\hline HUCB & $\begin{array}{l}\text { intravenous; } \\
\text { days }\end{array}$ & P7 rats & $\begin{array}{l}\text { Improved } \\
\text { performance }\end{array}$ & $\begin{array}{l}\text { Increased } \\
\text { dendritic density }\end{array}$ & 83 \\
\hline
\end{tabular}

ESCs, embryonic stem cells; HuNSCs, human neural stem cells; MSCs, mesenchymal stem cells; HUCBCs, human umbilical cord blood mononuclear cells; NE, not evaluated; ED, embryonic day; $P$, postnatal day 


\section{REFERENCES}

1. Allen MC. Neurodevelopmental outcomes of preterm infants. Curr Opin Neurol. 2008;21:123-128

2. Robertson CM, Watt MJ, Yasui Y. Changes in the prevalence of cerebral palsy for children born very prematurely within a population-based program over 30 years. Jama. 2007;297:2733-2740

3. Vincer MJ, Allen AC, Joseph KS et al. Increasing prevalence of cerebral palsy among very preterm infants: a population-based study. Pediatrics. 2006;118:e1621-1626

4. Wilson-Costello D, Friedman H, Minich N et al. Improved neurodevelopmental outcomes for extremely low birth weight infants in 2000-2002. Pediatrics. 2007;119:37-45

5. Volpe JJ. Neurobiology of periventricular leukomalacia in the premature infant. Pediatr Res. 2001;50:553-562

6. Craig A, Ling Luo N, Beardsley DJ et al. Quantitative analysis of perinatal rodent oligodendrocyte lineage progression and its correlation with human. Exp Neurol. 2003;181:231-240

7. Back SA, Han BH, Luo NL et al. Selective vulnerability of late oligodendrocyte progenitors to hypoxia-ischemia. J Neurosci. 2002;22:455-463

8. Inder TE, Warfield SK, Wang $\mathrm{H}$ et al. Abnormal cerebral structure is present at term in premature infants. Pediatrics. 2005;115:286-294

9. Volpe JJ. Encephalopathy of prematurity includes neuronal abnormalities. Pediatrics. 2005;116:221-225

10. Kesler SR, Vohr B, Schneider KC et al. Increased temporal lobe gyrification in preterm children. Neuropsychologia. 2006;44:445-453

11. Leviton A, Gressens P. Neuronal damage accompanies perinatal white-matter damage. Trends Neurosci. 2007;30:473-478

12. Marlow N, Wolke D, Bracewell MA, Samara M. Neurologic and developmental disability at six years of age after extremely preterm birth. N Engl J Med. 2005;352:9-19

13. O'Shea M. Cerebral palsy. Semin Perinatol. 2008;32:35-41

14. Silbereis JC, Huang EJ, Back SA, Rowitch DH. Towards improved animal models of neonatal white matter injury associated with cerebral palsy. Dis Model Mech. 2010;3:678-688

15. Zhen G, Dore S. Optimized protocol to reduce variable outcomes for the bilateral common carotid artery occlusion model in mice. J Neurosci Methods. 2007;166:73-80

16. Howells DW, Porritt MJ, Rewell SS et al. Different strokes for different folks: the rich diversity of animal models of focal cerebral ischemia. J Cereb Blood Flow Metab. 2010;30:1412-1431

17. Popp A, Jaenisch N, Witte OW, Frahm C. Identification of ischemic regions in a rat model of stroke. PLoS One. 2009;4:e4764

18. Hagberg H, Peebles D, Mallard C. Models of white matter injury: comparison of infectious, hypoxic-ischemic, and excitotoxic insults. Ment Retard Dev Disabil Res Rev. 2002;8:30-38

19. Follett PL, Deng W, Dai W et al. Glutamate receptor-mediated oligodendrocyte toxicity in periventricular leukomalacia: a protective role for topiramate. $J$ Neurosci. 2004;24:4412-4420

20. Vannucci RC, Connor JR, Mauger DT et al. Rat model of perinatal hypoxic-ischemic brain damage. J Neurosci Res. 1999;55:158-163 
21. Vannucci SJ, Hagberg H. Hypoxia-ischemia in the immature brain. J Exp Biol. 2004;207:3149-3154

22. Pang Y, Cai Z, Rhodes PG. Disturbance of oligodendrocyte development, hypomyelination and white matter injury in the neonatal rat brain after intracerebral injection of lipopolysaccharide. Brain Res Dev Brain Res. 2003;140:205-214

23. Fan LW, Tien LT, Mitchell HJ et al. Alpha-phenyl-n-tert-butyl-nitrone ameliorates hippocampal injury and improves learning and memory in juvenile rats following neonatal exposure to lipopolysaccharide. Eur J Neurosci. 2008;27:1475-1484

24. Lehnardt S, Lachance C, Patrizi S et al. The toll-like receptor TLR4 is necessary for lipopolysaccharide-induced oligodendrocyte injury in the CNS. J Neurosci. 2002;22:2478-2486

25. Cai Z, Pan ZL, Pang Y et al. Cytokine induction in fetal rat brains and brain injury in neonatal rats after maternal lipopolysaccharide administration. Pediatr Res. 2000;47:6472

26. Wang X, Rousset CI, Hagberg H, Mallard C. Lipopolysaccharide-induced inflammation and perinatal brain injury. Semin Fetal Neonatal Med. 2006;11:343-353

27. Johnston MV. Excitotoxicity in perinatal brain injury. Brain Pathol. 2005;15:234-240

28. Deng W, Pleasure J, Pleasure D. Progress in periventricular leukomalacia. Arch Neurol. 2008; 65:1291-1295

29. Inglis WL, Semba K. Discriminable excitotoxic effects of ibotenic acid, AMPA, NMDA and quinolinic acid in the rat laterodorsal tegmental nucleus. Brain Res. 1997;755:17-27

30. Cao Q, Benton RL, Whittemore SR. Stem cell repair of central nervous system injury. J Neurosci Res. 2002;68:501-510

31. Conti L, Cataudella T, Cattaneo E. Neural stem cells: a pharmacological tool for brain diseases? Pharmacol Res. 2003;47:289-297

32. Pluchino S, Zanotti L, Rossi B et al. Neurosphere-derived multipotent precursors promote neuroprotection by an immunomodulatory mechanism. Nature. 2005;436:266-271

33. Windrem MS, Schanz SJ, Guo M et al. Neonatal chimerization with human glial progenitor cells can both remyelinate and rescue the otherwise lethally hypomyelinated shiverer mouse. Cell Stem Cell. 2008;2:553-565

34. Kim SU, de Vellis J. Stem cell-based cell therapy in neurological diseases: a review. J Neurosci Res. 2009;87:2183-2200

35. Pimentel-Coelho PM, Mendez-Otero R. Cell therapy for neonatal hypoxic-ischemic encephalopathy. Stem Cells Dev. 2010;19:299-310

36. Sato Y, Nakanishi K, Hayakawa M et al. Reduction of brain injury in neonatal hypoxicischemic rats by intracerebroventricular injection of neural stem/progenitor cells together with chondroitinase ABC. Reprod Sci. 2008;15:613-620

37. Zheng T, Marshall Ii GP, 2nd, Chen KA, Laywell ED. Transplantation of neural stem/progenitor cells into developing and adult CNS. Methods Mol Biol. 2009;482:185197

38. Comi AM, Cho E, Mulholland JD et al. Neural stem cells reduce brain injury after unilateral carotid ligation. Pediatr Neurol. 2008;38:86-92

39. Titomanlio L, Bouslama M, Le Verche V et al. implanted neurosphere-derived precursors promote recovery after neonatal excitotoxic brain injury. Stem Cells Dev. 2011;20:865-79

40. van Velthoven CT, Kavelaars A, van Bel F, Heijnen CJ. Mesenchymal stem cell treatment after neonatal hypoxic-ischemic brain injury improves behavioral outcome and 
induces neuronal and oligodendrocyte regeneration. Brain Behav Immun. 2010;24:387393

41. van Velthoven CT, Kavelaars A, van Bel F, Heijnen CJ. Nasal administration of stem cells: a promising novel route to treat neonatal ischemic brain damage. Pediatr Res. 2010;68:419-422

42. Lee HJ, Lim IJ, Lee MC, Kim SU. Human neural stem cells genetically modified to overexpress brain-derived neurotrophic factor promote functional recovery and neuroprotection in a mouse stroke model. J Neurosci Res. 2010;88:3282-3294

43. Alvarez-Buylla A, Temple S. Stem cells in the developing and adult nervous system. J Neurobiol. 1998;36:105-110

44. Gage FH. Mammalian neural stem cells. Science. 2000;287:1433-1438

45. Weiss S, Reynolds BA, Vescovi AL et al. Is there a neural stem cell in the mammalian forebrain? Trends Neurosci. 1996;19:387-393

46. Gritti A, Bonfanti L, Doetsch F et al. Multipotent neural stem cells reside into the rostral extension and olfactory bulb of adult rodents. J Neurosci. 2002;22:437-445

47. Johe KK, Hazel TG, Muller T et al. Single factors direct the differentiation of stem cells from the fetal and adult central nervous system. Genes Dev. 1996;10:3129-3140

48. Reynolds BA, Weiss S. Generation of neurons and astrocytes from isolated cells of the adult mammalian central nervous system. Science. 1992;255:1707-1710

49. Reynolds BA, Weiss S. Clonal and population analyses demonstrate that an EGFresponsive mammalian embryonic CNS precursor is a stem cell. Dev Biol. 1996;175:1-13

50. Englund U, Bjorklund A, Wictorin $\mathrm{K}$ et al. Grafted neural stem cells develop into functional pyramidal neurons and integrate into host cortical circuitry. Proc Natl Acad Sci U S A. 2002;99:17089-17094

51. Scheffler B, Schmandt T, Schroder W et al. Functional network integration of embryonic stem cell-derived astrocytes in hippocampal slice cultures. Development. 2003;130:55335541

52. Corti S, Locatelli F, Papadimitriou D et al. Multipotentiality, homing properties, and pyramidal neurogenesis of CNS-derived LeX(ssea-1)+/CXCR4+ stem cells. Faseb J. 2005; 19:1860-1862

53. Bjorklund LM, Sanchez-Pernaute R, Chung S et al. Embryonic stem cells develop into functional dopaminergic neurons after transplantation in a Parkinson rat model. Proc Natl Acad Sci U S A. 2002;99:2344-2349

54. Carson CT, Aigner S, Gage FH. Stem cells: the good, bad and barely in control. Nat Med. 2006; $12: 1237-1238$

55. Chung S, Shin BS, Hedlund E et al. Genetic selection of sox 1GFP-expressing neural precursors removes residual tumorigenic pluripotent stem cells and attenuates tumor formation after transplantation. J Neurochem. 2006;97:1467-1480

56. Takahashi K, Yamanaka S. Induction of pluripotent stem cells from mouse embryonic and adult fibroblast cultures by defined factors. Cell. 2006;126:663-676

57. Takahashi K, Tanabe K, Ohnuki $\mathrm{M}$ et al. Induction of pluripotent stem cells from adult human fibroblasts by defined factors. Cell. 2007;131:861-872

58. Yu J, Vodyanik MA, Smuga-Otto K et al. Induced pluripotent stem cell lines derived from human somatic cells. Science. 2007;318:1917-1920

59. Salewski RP, Eftekharpour E, Fehlings MG. Are induced pluripotent stem cells the future of cell-based regenerative therapies for spinal cord injury? J Cell Physiol. 2010;222:515521 
60. Vierbuchen T, Ostermeier A, Pang ZP et al. Direct conversion of fibroblasts to functional neurons by defined factors. Nature. 2010;463:1035-1041

61. Szabo E, Rampalli S, Risueno RM et al. Direct conversion of human fibroblasts to multilineage blood progenitors. Nature. 2010;468:521-6

62. Kohyama J, Abe H, Shimazaki T et al. Brain from bone: efficient "meta-differentiation" of marrow stroma-derived mature osteoblasts to neurons with Noggin or a demethylating agent. Differentiation. 2001;68:235-244

63. Dezawa M, Kanno H, Hoshino $\mathrm{M}$ et al. Specific induction of neuronal cells from bone marrow stromal cells and application for autologous transplantation. J Clin Invest. 2004;113:1701-1710

64. Woodbury D, Schwarz EJ, Prockop DJ, Black IB. Adult rat and human bone marrow stromal cells differentiate into neurons. J Neurosci Res. 2000;61:364-370

65. Sanchez-Ramos J, Song S, Cardozo-Pelaez F et al. Adult bone marrow stromal cells differentiate into neural cells in vitro. Exp Neurol. 2000;164:247-256

66. Suzuki H, Taguchi T, Tanaka H et al. Neurospheres induced from bone marrow stromal cells are multipotent for differentiation into neuron, astrocyte, and oligodendrocyte phenotypes. Biochem Biophys Res Commun. 2004;322:918-922

67. Hermann A, Liebau S, Gastl $\mathrm{R}$ et al. Comparative analysis of neuroectodermal differentiation capacity of human bone marrow stromal cells using various conversion protocols. J Neurosci Res. 2006;83:1502-1514

68. Montzka K, Lassonczyk N, Tschoke B et al. Neural differentiation potential of human bone marrow-derived mesenchymal stromal cells: misleading marker gene expression. BMC Neurosci. 2009; 10:16

69. Lu P, Blesch A, Tuszynski MH. Induction of bone marrow stromal cells to neurons: differentiation, transdifferentiation, or artifact? J Neurosci Res. 2004;77:174-191

70. Neuhuber B, Gallo G, Howard L et al. Reevaluation of in vitro differentiation protocols for bone marrow stromal cells: disruption of actin cytoskeleton induces rapid morphological changes and mimics neuronal phenotype. J Neurosci Res. 2004;77:192204

71. Bertani N, Malatesta P, Volpi G et al. Neurogenic potential of human mesenchymal stem cells revisited: analysis by immunostaining, time-lapse video and microarray. J Cell Sci. 2005;118:3925-3936

72. Choi CB, Cho YK, Prakash KV et al. Analysis of neuron-like differentiation of human bone marrow mesenchymal stem cells. Biochem Biophys Res Commun. 2006;350:138146

73. Pappa KI, Anagnou NP. Novel sources of fetal stem cells: where do they fit on the developmental continuum? Regen Med. 2009;4:423-433

74. Kaplan JM, Youd ME, Lodie TA. Immunomodulatory Activity of Mesenchymal Stem

Cells. Curr Stem Cell Res Ther 2011, in press (PMID:21190531)

75. Sato K, Ozaki K, Mori M et al. Mesenchymal stromal cells for graft-versus-host disease : basic aspects and clinical outcomes. J Clin Exp Hematop. 2010;50:79-89

76. Lee MW, Yang MS, Park JS et al. Isolation of mesenchymal stem cells from cryopreserved human umbilical cord blood. Int J Hematol. 2005;81:126-130

77. Ingram DA, Mead LE, Tanaka $\mathrm{H}$ et al. Identification of a novel hierarchy of endothelial progenitor cells using human peripheral and umbilical cord blood. Blood. 2004;104:27522760 
78. Broxmeyer HE. Umbilical cord transplantation: epilogue. Semin Hematol. 2010;47:97103

79. Kurtzberg J. Update on umbilical cord blood transplantation. Curr Opin Pediatr. 2009;21:22-29

80. Kogler G, Sensken S, Airey JA et al. A new human somatic stem cell from placental cord blood with intrinsic pluripotent differentiation potential. J Exp Med. 2004;200:123-135

81. Pimentel-Coelho PM, Magalhaes ES, Lopes LM et al. Human cord blood transplantation in a neonatal rat model of hypoxic-ischemic brain damage: functional outcome related to neuroprotection in the striatum. Stem Cells Dev. 2010;19:351-358

82. Meier C, Middelanis J, Wasielewski B et al. Spastic paresis after perinatal brain damage in rats is reduced by human cord blood mononuclear cells. Pediatr Res. 2006;59:244-249

83. Yasuhara T, Hara K, Maki M et al. Mannitol facilitates neurotrophic factor up-regulation and behavioural recovery in neonatal hypoxic-ischaemic rats with human umbilical cord blood grafts. J Cell Mol Med. 2010;14:914-921

84. de Paula S, Vitola AS, Greggio S et al. Hemispheric brain injury and behavioral deficits induced by severe neonatal hypoxia-ischemia in rats are not attenuated by intravenous administration of human umbilical cord blood cells. Pediatr Res. 2009;65:631-635

85. Markov V, Kusumi K, Tadesse MG et al. Identification of cord blood-derived mesenchymal stem/stromal cell populations with distinct growth kinetics, differentiation potentials, and gene expression profiles. Stem Cells Dev. 2007;16:53-73

86. Tondreau T, Meuleman N, Delforge A et al. Mesenchymal stem cells derived from CD133-positive cells in mobilized peripheral blood and cord blood: proliferation, Oct4 expression, and plasticity. Stem Cells. 2005;23:1105-1112

87. Gao F, Wu DQ, Hu YH et al. In vitro cultivation of islet-like cell clusters from human umbilical cord blood-derived mesenchymal stem cells. Transl Res. 2008;151:293-302

88. Haase A, Olmer R, Schwanke K et al. Generation of induced pluripotent stem cells from human cord blood. Cell Stem Cell. 2009;5:434-441

89. Das H, Abdulhameed N, Joseph $\mathrm{M}$ et al. Ex vivo nanofiber expansion and genetic modification of human cord blood-derived progenitor/stem cells enhances vasculogenesis. Cell Transplant. 2009;18:305-318

90. Buzanska L, Jurga M, Stachowiak EK et al. Neural stem-like cell line derived from a nonhematopoietic population of human umbilical cord blood. Stem Cells Dev. 2006;15:391-406

91. Jang YK, Park JJ, Lee MC et al. Retinoic acid-mediated induction of neurons and glial cells from human umbilical cord-derived hematopoietic stem cells. J Neurosci Res. 2004;75:573-584

92. Broxmeyer HE. Will iPS cells enhance therapeutic applicability of cord blood cells and banking? Cell Stem Cell. 2010;6:21-24

93. Rocha V, Wagner JE, Jr., Sobocinski KA et al. Graft-versus-host disease in children who have received a cord-blood or bone marrow transplant from an HLA-identical sibling. Eurocord and International Bone Marrow Transplant Registry Working Committee on Alternative Donor and Stem Cell Sources. N Engl J Med. 2000;342:1846-1854

94. Borlongan CV, Hadman M, Sanberg CD, Sanberg PR. Central nervous system entry of peripherally injected umbilical cord blood cells is not required for neuroprotection in stroke. Stroke. 2004;35:2385-2389 
95. Vendrame M, Cassady J, Newcomb J et al. Infusion of human umbilical cord blood cells in a rat model of stroke dose-dependently rescues behavioral deficits and reduces infarct volume. Stroke. 2004;35:2390-2395

96. Baksh D, Yao R, Tuan RS. Comparison of proliferative and multilineage differentiation potential of human mesenchymal stem cells derived from umbilical cord and bone marrow. Stem Cells. 2007;25:1384-1392

97. Fujiwara Y, Tanaka N, Ishida $\mathrm{O}$ et al. Intravenously injected neural progenitor cells of transgenic rats can migrate to the injured spinal cord and differentiate into neurons, astrocytes and oligodendrocytes. Neurosci Lett. 2004;366:287-291

98. Danielyan L, Schafer R, von Ameln-Mayerhofer A et al. Intranasal delivery of cells to the brain. Eur J Cell Biol. 2009;88:315-324

99. Stroemer P, Patel S, Hope A et al. The neural stem cell line CTX0E03 promotes behavioral recovery and endogenous neurogenesis after experimental stroke in a dosedependent fashion. Neurorehabil Neural Repair. 2009;23:895-909

100. Schwarz SC, Schwarz J. Translation of stem cell therapy for neurological diseases. Transl Res. 2010;156:155-160

101. Bjarkam CR, Glud AN, Margolin L et al. Safety and function of a new clinical intracerebral microinjection instrument for stem cells and therapeutics examined in the Gottingen minipig. Stereotact Funct Neurosurg. 2010;88:56-63

102. Guillaume DJ, Huhn SL, Selden NR, Steiner RD. Cellular therapy for childhood neurodegenerative disease. Part I: rationale and preclinical studies. Neurosurg Focus. 2008;24:E22

103. van Velthoven CT, Kavelaars A, van Bel F, Heijnen CJ. Repeated mesenchymal stem cell treatment after neonatal hypoxia-ischemia has distinct effects on formation and maturation of new neurons and oligodendrocytes leading to restoration of damage, corticospinal motor tract activity, and sensorimotor function. J Neurosci. 2010;30:96039611

104. Sykova E, Jendelova P. Migration, fate and in vivo imaging of adult stem cells in the CNS. Cell Death Differ. 2007;14:1336-1342

105. Adams HP, Jr., del Zoppo G, Alberts MJ et al. Guidelines for the early management of adults with ischemic stroke: a guideline from the American Heart Association/American Stroke Association Stroke Council, Clinical Cardiology Council, Cardiovascular Radiology and Intervention Council, and the Atherosclerotic Peripheral Vascular Disease and Quality of Care Outcomes in Research Interdisciplinary Working Groups: The American Academy of Neurology affirms the value of this guideline as an educational tool for neurologists. Circulation. 2007;115:e478-534

106. Adams HP, Jr., del Zoppo G, Alberts MJ et al. Guidelines for the early management of adults with ischemic stroke: a guideline from the American Heart Association/American Stroke Association Stroke Council, Clinical Cardiology Council, Cardiovascular Radiology and Intervention Council, and the Atherosclerotic Peripheral Vascular Disease and Quality of Care Outcomes in Research Interdisciplinary Working Groups: the American Academy of Neurology affirms the value of this guideline as an educational tool for neurologists. Stroke. 2007;38:1655-1711

107. Chen J, Li Y, Katakowski M et al. Intravenous bone marrow stromal cell therapy reduces apoptosis and promotes endogenous cell proliferation after stroke in female rat. J Neurosci Res. 2003;73:778-786 
108. Okazaki $\mathrm{T}$, Magaki $\mathrm{T}$, Takeda $\mathrm{M}$ et al. Intravenous administration of bone marrow stromal cells increases survivin and Bcl-2 protein expression and improves sensorimotor function following ischemia in rats. Neurosci Lett. 2008;430:109-114

109. Zhang $\mathrm{C}, \mathrm{Li} \mathrm{Y}$, Chen J et al. Bone marrow stromal cells upregulate expression of bone morphogenetic proteins 2 and 4, gap junction protein connexin-43 and synaptophysin after stroke in rats. Neuroscience. 2006;141:687-695

110. Ferriero DM. Neonatal brain injury. N Engl J Med. 2004;351:1985-1995

111. Degos V, Favrais G, Kaindl AM et al. Inflammation processes in perinatal brain damage. J Neural Transm. 2010;117:1009-1017

112. Kounami S, Aoyagi N, Nakayama $\mathrm{K}$ et al. Fatal pulmonary thromboembolism after a second course of high-dose chemotherapy with autologous peripheral blood stem cell transplantation. Pediatr Transplant. 2003;7:400-403

113. Morales IJ, Anderson PM, Tazelaar HD, Wylam ME. Pulmonary cytolytic thrombi: unusual complication of hematopoietic stem cell transplantation. J Pediatr Hematol Oncol. 2003;25:89-92

114. Walczak P, Zhang J, Gilad AA et al. Dual-modality monitoring of targeted intraarterial delivery of mesenchymal stem cells after transient ischemia. Stroke. 2008;39:1569-1574

115. Nishino $\mathrm{H}$, Borlongan $\mathrm{CV}$. Restoration of function by neural transplantation in the ischemic brain. Prog Brain Res. 2000;127:461-476

116. Rosenkranz K, Kumbruch S, Lebermann K et al. The chemokine SDF-1/CXCL12 contributes to the 'homing' of umbilical cord blood cells to a hypoxic-ischemic lesion in the rat brain. J Neurosci Res. 2010;88:1223-1233

117. Abe K. Therapeutic potential of neurotrophic factors and neural stem cells against ischemic brain injury. J Cereb Blood Flow Metab. 2000;20:1393-1408

118. Imitola J, Raddassi K, Park KI et al. Directed migration of neural stem cells to sites of CNS injury by the stromal cell-derived factor 1 alpha/CXC chemokine receptor 4 pathway. Proc Natl Acad Sci U S A. 2004;101:18117-18122

119. Duncan ID. Oligodendrocytes and stem cell transplantation: their potential in the treatment of leukoencephalopathies. J Inherit Metab Dis. 2005;28:357-368

120. McKenzie IA, Biernaskie J, Toma JG et al. Skin-derived precursors generate myelinating Schwann cells for the injured and dysmyelinated nervous system. J Neurosci. 2006;26:6651-6660

121. Tran KD, Ho A, Jandial R. Stem cell transplantation methods. Adv Exp Med Biol. 2010;671:41-57

122. Guzman R, Uchida N, Bliss TM et al. Long-term monitoring of transplanted human neural stem cells in developmental and pathological contexts with MRI. Proc Natl Acad Sci U S A. 2007;104:10211-10216

123. Neri M, Maderna C, Cavazzin $\mathrm{C}$ et al. Efficient in vitro labeling of human neural precursor cells with superparamagnetic iron oxide particles: relevance for in vivo cell tracking. Stem Cells. 2008;26:505-516

124. Manganas LN, Zhang X, Li Y et al. Magnetic resonance spectroscopy identifies neural progenitor cells in the live human brain. Science. 2007;318:980-985

125. Politi LS. MR-based imaging of neural stem cells. Neuroradiology. 2007;49:523-534

126. Deng J, Petersen BE, Steindler DA et al. Mesenchymal stem cells spontaneously express neural proteins in culture and are neurogenic after transplantation. Stem Cells. 2006;24:1054-1064 
127. Nag S, Kapadia A, Stewart DJ. Molecular Pathogenesis of Blood-Brain Barrier Breakdown in Acute Brain Injury. Neuropathol Appl Neurobiol. 2011;37(1):3-23

128. Coyne TM, Marcus AJ, Woodbury D, Black IB. Marrow stromal cells transplanted to the adult brain are rejected by an inflammatory response and transfer donor labels to host neurons and glia. Stem Cells. 2006;24:2483-2492

129. Spaggiari GM, Capobianco A, Abdelrazik H et al. Mesenchymal stem cells inhibit natural killer-cell proliferation, cytotoxicity, and cytokine production: role of indoleamine 2,3dioxygenase and prostaglandin E2. Blood. 2008;111:1327-1333

130. Freed CR, Greene PE, Breeze RE et al. Transplantation of embryonic dopamine neurons for severe Parkinson's disease. N Engl J Med. 2001;344:710-719

131. Olanow CW, Goetz CG, Kordower JH et al. A double-blind controlled trial of bilateral fetal nigral transplantation in Parkinson's disease. Ann Neurol. 2003;54:403-414

132. Freeman TB, Cicchetti F, Hauser RA et al. Transplanted fetal striatum in Huntington's disease: phenotypic development and lack of pathology. Proc Natl Acad Sci U S A. 2000;97:13877-13882

133. Keene CD, Sonnen JA, Swanson PD et al. Neural transplantation in Huntington disease: long-term grafts in two patients. Neurology. 2007;68:2093-2098

134. Tai YT, Svendsen CN. Stem cells as a potential treatment of neurological disorders. Curr Opin Pharmacol. 2004;4:98-104

135. Lepore AC, Neuhuber B, Connors TM et al. Long-term fate of neural precursor cells following transplantation into developing and adult CNS. Neuroscience. 2006;142:287304

136. Hess PG. Risk of tumorigenesis in first-in-human trials of embryonic stem cell neural derivatives: Ethics in the face of long-term uncertainty. Account Res. 2009;16:175-198

137. Low CB, Liou YC, Tang BL. Neural differentiation and potential use of stem cells from the human umbilical cord for central nervous system transplantation therapy. J Neurosci Res. 2008;86:1670-1679

138. Gruen L, Grabel L. Concise review: scientific and ethical roadblocks to human embryonic stem cell therapy. Stem Cells. 2006;24:2162-2169

139. Amariglio N, Hirshberg A, Scheithauer BW et al. Donor-derived brain tumor following neural stem cell transplantation in an ataxia telangiectasia patient. PLoS Med. 2009;6:e1000029

140. Windrem MS, Nunes MC, Rashbaum WK et al. Fetal and adult human oligodendrocyte progenitor cell isolates myelinate the congenitally dysmyelinated brain. Nat Med. 2004;10:93-97

141. Tahraoui SL, Marret S, Bodenant C et al. Central role of microglia in neonatal excitotoxic lesions of the murine periventricular white matter. Brain Pathol. 2001;11:56-71

142. Lodygensky GA, Vasung L, Sizonenko SV, Huppi PS. Neuroimaging of cortical development and brain connectivity in human newborns and animal models. J Anat. 2010;217:418-428

143. Yager JY, Ashwal S. Animal models of perinatal hypoxic-ischemic brain damage. Pediatr Neurol. 2009;40:156-167

144. Scafidi J, Fagel DM, Ment LR, Vaccarino FM. Modeling premature brain injury and recovery. Int J Dev Neurosci. 2009;27:863-871

145. Dihne M, Bernreuther C, Hagel C et al. Embryonic stem cell-derived neuronally committed precursor cells with reduced teratoma formation after transplantation into the lesioned adult mouse brain. Stem Cells. 2006;24:1458-1466 
146. Mueller D, Shamblott MJ, Fox HE et al. Transplanted human embryonic germ cellderived neural stem cells replace neurons and oligodendrocytes in the forebrain of neonatal mice with excitotoxic brain damage. J Neurosci Res. 2005;82:592-608

147. Daadi MM, Davis AS, Arac A et al. Human neural stem cell grafts modify microglial response and enhance axonal sprouting in neonatal hypoxic-ischemic brain injury. Stroke. 2010;41:516-523

148. Yasuhara T, Hara K, Maki M et al. Intravenous grafts recapitulate the neurorestoration afforded by intracerebrally delivered multipotent adult progenitor cells in neonatal hypoxic-ischemic rats. J Cereb Blood Flow Metab. 2008;28:1804-1810

149. Li Y, Chen J, Chen XG et al. Human marrow stromal cell therapy for stroke in rat: neurotrophins and functional recovery. Neurology. 2002;59:514-523

150. Shen LH, Li Y, Chen J et al. One-year follow-up after bone marrow stromal cell treatment in middle-aged female rats with stroke. Stroke. 2007;38:2150-2156

151. Bondolfi L, Ermini F, Long JM et al. Impact of age and caloric restriction on neurogenesis in the dentate gyrus of C57BL/6 mice. Neurobiol Aging. 2004;25:333-340

152. Kuhn HG, Dickinson-Anson H, Gage FH. Neurogenesis in the dentate gyrus of the adult rat: age-related decrease of neuronal progenitor proliferation. J Neurosci. 1996;16:20272033

153. Leuner B, Kozorovitskiy Y, Gross CG, Gould E. Diminished adult neurogenesis in the marmoset brain precedes old age. Proc Natl Acad Sci U S A. 2007;104:17169-17173

154. Zigova T, Song S, Willing AE et al. Human umbilical cord blood cells express neural antigens after transplantation into the developing rat brain. Cell Transplant. 2002;11:265274

155. Wurmser AE, Nakashima K, Summers RG et al. Cell fusion-independent differentiation of neural stem cells to the endothelial lineage. Nature. 2004;430:350-356

156. Kelly S, Bliss TM, Shah AK et al. Transplanted human fetal neural stem cells survive, migrate, and differentiate in ischemic rat cerebral cortex. Proc Natl Acad Sci U S A. 2004; 101:11839-11844

157. Park KI, Lachyankar M, Nissim S, Snyder EY. Neural stem cells for CNS repair: state of the art and future directions. Adv Exp Med Biol. 2002;506:1291-1296

158. Ourednik J, Ourednik V, Lynch WP et al. Neural stem cells display an inherent mechanism for rescuing dysfunctional neurons. Nat Biotechnol. 2002;20:1103-1110

159. Pluchino S, Quattrini A, Brambilla E et al. Injection of adult neurospheres induces recovery in a chronic model of multiple sclerosis. Nature. 2003;422:688-694

160. Sinden JD, Rashid-Doubell F, Kershaw TR et al. Recovery of spatial learning by grafts of a conditionally immortalized hippocampal neuroepithelial cell line into the ischaemialesioned hippocampus. Neuroscience. 1997;81:599-608

161. Aharonowiz M, Einstein O, Fainstein $\mathrm{N}$ et al. Neuroprotective effect of transplanted human embryonic stem cell-derived neural precursors in an animal model of multiple sclerosis. PLoS One. 2008;3:e3145

162. Ben-Hur T. Immunomodulation by neural stem cells. J Neurol Sci. 2008;265:102-104

163. Einstein $\mathrm{O}$, Ben-Hur T. The changing face of neural stem cell therapy in neurologic diseases. Arch Neurol. 2008;65:452-456

164. Locatelli F, Bersano A, Ballabio E et al. Stem cell therapy in stroke. Cell Mol Life Sci. 2009;66:757-772

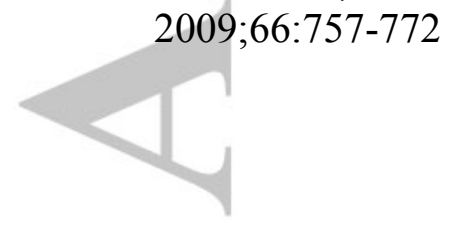


165. Bacigaluppi M, Pluchino S, Peruzzotti Jametti L et al. Delayed post-ischaemic neuroprotection following systemic neural stem cell transplantation involves multiple mechanisms. Brain. 2009;132:2239-2251

166. Pluchino S, Cusimano M, Bacigaluppi M, Martino G. Remodelling the injured CNS through the establishment of atypical ectopic perivascular neural stem cell niches. Arch Ital Biol. 2010;148:173-183

167. Lee ST, Chu K, Jung KH et al. Anti-inflammatory mechanism of intravascular neural stem cell transplantation in haemorrhagic stroke. Brain. 2008;131:616-629

168. Prowse AB, Chong F, Gray PP, Munro TP. Stem cell integrins: implications for ex-vivo culture and cellular therapies. Stem Cell Res. 2011;6:1-12

169. Keirstead HS, Nistor G, Bernal G et al. Human embryonic stem cell-derived oligodendrocyte progenitor cell transplants remyelinate and restore locomotion after spinal cord injury. J Neurosci. 2005;25:4694-4705

170. Mathieu P, Battista D, Depino A et al. The more you have, the less you get: the functional role of inflammation on neuronal differentiation of endogenous and transplanted neural stem cells in the adult brain. J Neurochem. 2010;112:1368-1385

171. Pollock K, Stroemer P, Patel S et al. A conditionally immortal clonal stem cell line from human cortical neuroepithelium for the treatment of ischemic stroke. Exp Neurol. 2006;199:143-155

172. Tamaki SJ, Jacobs Y, Dohse M et al. Neuroprotection of host cells by human central nervous system stem cells in a mouse model of infantile neuronal ceroid lipofuscinosis. Cell Stem Cell. 2009;5:310-319

173. Escolar ML, Poe MD, Provenzale JM et al. Transplantation of umbilical-cord blood in babies with infantile Krabbe's disease. N Engl J Med. 2005;352:2069-2081

174. Sun J, Allison J, McLaughlin C et al. Differences in quality between privately and publicly banked umbilical cord blood units: a pilot study of autologous cord blood infusion in children with acquired neurologic disorders. Transfusion. 2010;50:1980-1987

175. Gluckman E, Rocha V, Chastang C. Peripheral stem cells in bone marrow transplantation. Cord blood stem cell transplantation. Baillieres Best Pract Res Clin Haematol. 1999;12:279-292

176. Kaufman DS, Thomson JA. Human ES cells--haematopoiesis and transplantation strategies. J Anat. 2002;200:243-248

177. Zhang SC. Embryonic stem cells for neural replacement therapy: prospects and challenges. J Hematother Stem Cell Res. 2003;12:625-634

178. Muller FJ, Snyder EY, Loring JF. Gene therapy: can neural stem cells deliver? Nat Rev Neurosci. 2006;7:75-84

179. Horita $\mathrm{Y}$, Honmou O, Harada $\mathrm{K}$ et al. Intravenous administration of glial cell line-derived neurotrophic factor gene-modified human mesenchymal stem cells protects against injury in a cerebral ischemia model in the adult rat. J Neurosci Res. 2006;84:1495-1504

180. Elsayed MH, Hogan TP, Shaw PL, Castro AJ. Use of fetal cortical grafts in hypoxicischemic brain injury in neonatal rats. Exp Neurol. 1996;137:127-141

181. Jansen EM, Solberg L, Underhill S et al. Transplantation of fetal neocortex ameliorates sensorimotor and locomotor deficits following neonatal ischemic-hypoxic brain injury in rats. Exp Neurol. 1997;147:487-497

182. Ma J, Wang Y, Yang J et al. Treatment of hypoxic-ischemic encephalopathy in mouse by transplantation of embryonic stem cell-derived cells. Neurochem Int. 2007;51:57-65 
183. Lee JP, Jeyakumar M, Gonzalez R et al. Stem cells act through multiple mechanisms to benefit mice with neurodegenerative metabolic disease. Nat Med. 2007;13:439-447

184. Lee JA, Kim BI, Jo CH et al. Mesenchymal stem-cell transplantation for hypoxicischemic brain injury in neonatal rat model. Pediatr Res. 2010;67:42-46

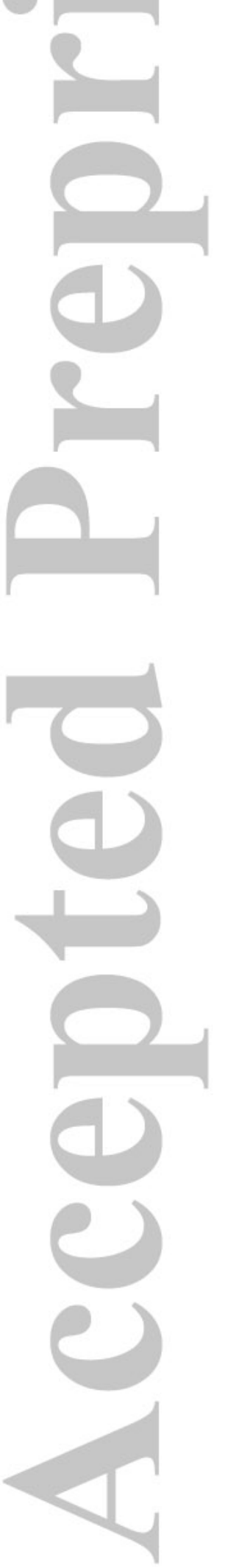



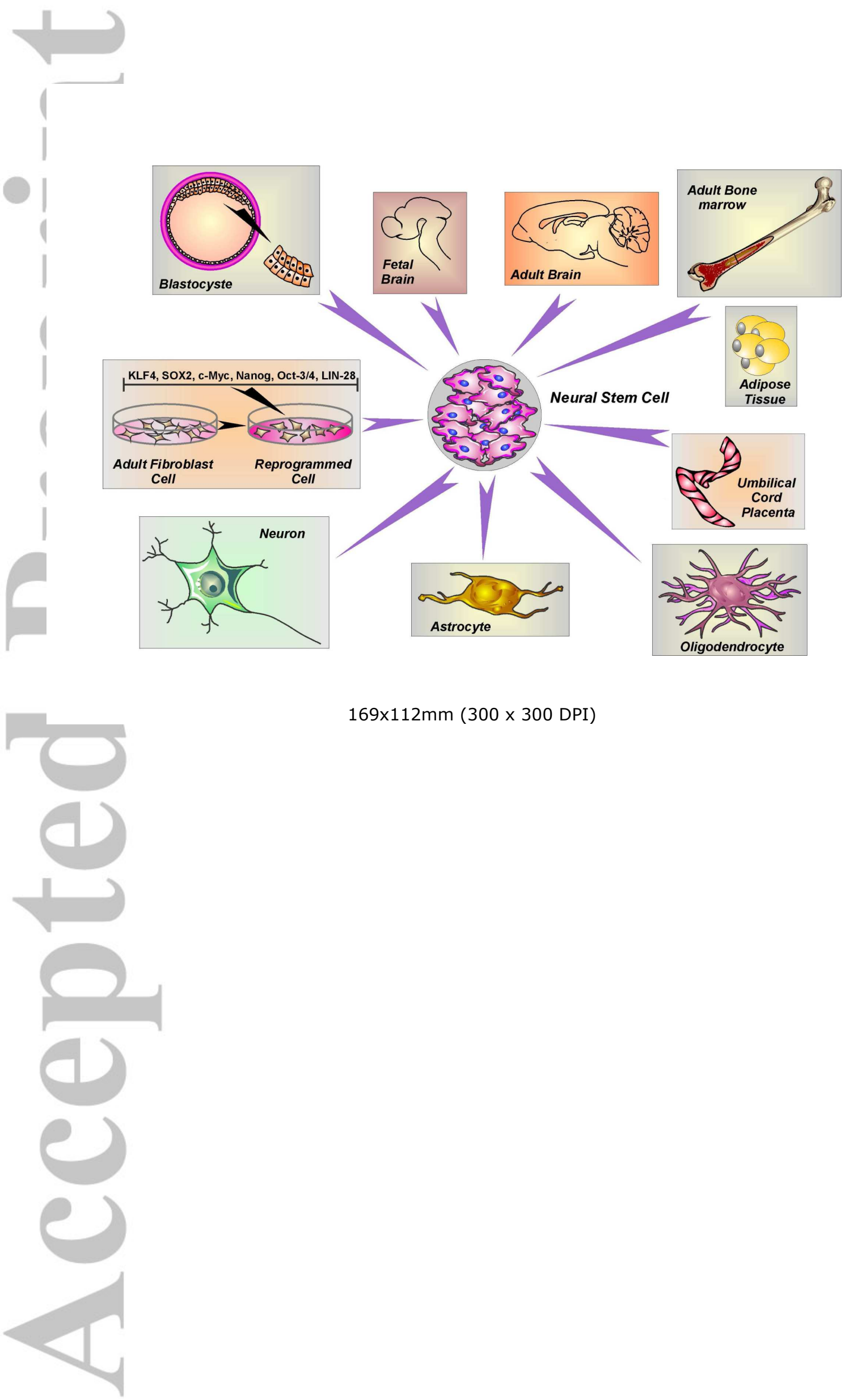

$169 \times 112 \mathrm{~mm}(300 \times 300 \mathrm{DPI})$ 


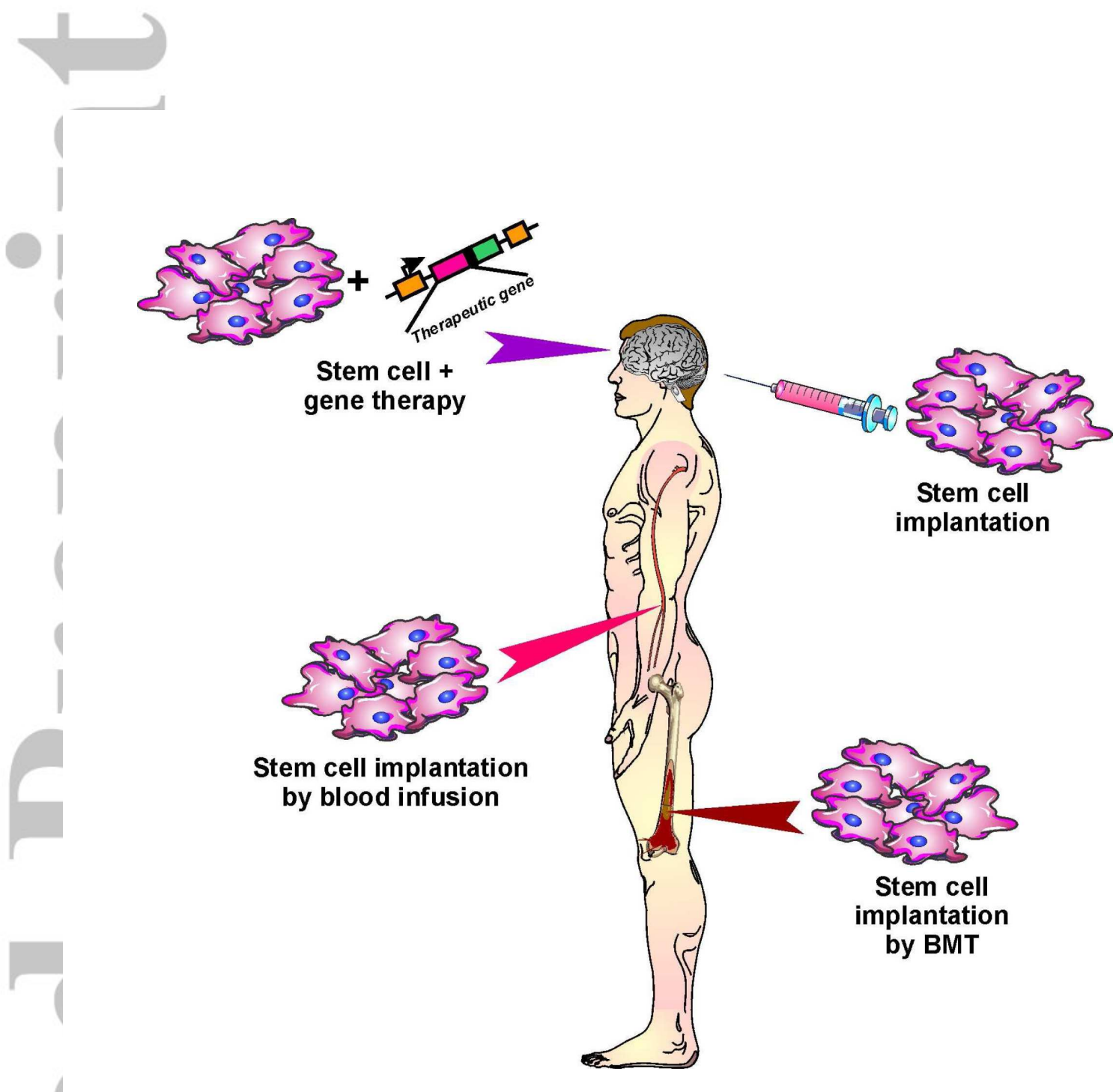

$170 \times 148 \mathrm{~mm}(300 \times 300 \mathrm{DPI})$ 